New Trichomycetes from Western China

Author(s): D. B. Strongman, Juan Wang and Shengquan Xu

Source: Mycologia, Vol. 102, No. 1 (Jan. - Feb., 2010), pp. 174-184

Published by: Mycological Society of America

Stable URL: http://www.jstor.org/stable/20619280

Accessed: 17-06-2015 12:14 UTC

\title{
REFERENCES
}

Linked references are available on JSTOR for this article:

http://www.jstor.org/stable/20619280?seq=1\&cid=pdf-reference\#references_tab_contents

You may need to log in to JSTOR to access the linked references.

Your use of the JSTOR archive indicates your acceptance of the Terms \& Conditions of Use, available at http://www.jstor.org/page/ info/about/policies/terms.jsp

JSTOR is a not-for-profit service that helps scholars, researchers, and students discover, use, and build upon a wide range of content in a trusted digital archive. We use information technology and tools to increase productivity and facilitate new forms of scholarship. For more information about JSTOR, please contact support@jstor.org. 


\section{New trichomycetes from western China}

\author{
D.B. Strongman ${ }^{1}$ \\ Department of Biology, Saint Mary's University, \\ Halifax, Nova Scotia, Canada B3H 3 C3 \\ Juan Wang \\ Shengquan $\mathrm{Xu}$ \\ College of Life Science, Shaanxi Normal University, \\ Xi'an, PR China
}

\begin{abstract}
Data on trichomycete biodiversity in China is expanded with the description of three new fungal species, Legeriomyces grandis, Legeriosimilis elegans, Smittium shaanxiense, and a protist, Paramoebidium bacillare. The geographical distribution for the harpellid species, Glotzia ephemeridarum, Smittium culicis and Stachylina gravicaudata, is extended with their collection in western China, and five species previously known from Asia are also reported here.
\end{abstract}

Key words: gut fungi, Harpellales, insect endosymbionts, new species

\section{INTRODUCTION}

Symbiotic, gut-inhabiting fungi and protists (trichomycetes) are ubiquitous wherever their aquatic invertebrate hosts have been examined (Lichtwardt 1986, Lichtwardt et al 2001). However vast geographical areas with suitable habitat and potential hosts for trichomycetes have not yet been extensively surveyed (e.g. most of Asia, including China).

In China there have been few reports of trichomycete fungi, with Harpella melusinae Léger \& Deboscq being the first reported trichomycete (Adler et al 1996). Three new Smittium spp. and five other gut fungi were recorded from the Qinling Mountains in western China (Strongman and Xu 2006). Wang et al (2010) described a new genus and species, Sinotrichium chironomidarum J. Wang, S. Xu \& Strongman, as well as another new species, Stachylina tianensis J. Wang, S. Xu \& Strongman, both from chironomid larvae. Records of trichomycetes are sparse from other parts of Asia with collections in India (Misra 2002, Misra and Tiwari 2008) and an extensive survey in Japan by Lichtwardt et al (1987). Chien and Hsieh (2001) documented trichomycetes from marine habitats in Taiwan. Diversity of trichomycetes is undoubtedly immense in China given the abundance of habitats and suitable hosts in such a vast area, so

Submitted 24 Feb 2009; accepted for publication 29 Jun 2009.

${ }^{1}$ Corresponding author. E-mail: doug.strongman@smu.ca continued surveying for trichomycetes will add substantially to our knowledge of this group.

In this paper we add to the global trichomycete inventory in a small region of China by describing four new species, Legeriomyces grandis, Legeriosimilis elegans, Paramoebidium bacillare and Smittium shaanxiense, and recording new geographic records for four species of Harpellales from China.

\section{MATERIALS AND METHODS}

Immature, aquatic insects were collected from 11 sites on the north and south sides of the Qinling Mountains in western China May 2005-Apr 2007. The current report includes details on the locations, collection dates and site characteristics (TABLE I).

Insect specimens were collected with aquatic dip nets (30 $\mathrm{cm}$ gape, $0.5 \mathrm{~mm}$ mesh) by disturbing the substrate with the feet and capturing the dislodged hosts in the net (kick-sampling). The hindgut, as well as the peritrophic matrix in dipterans, were dissected from insect hosts in drops of water in Petri plates on the stage of a stereomicroscope equipped with a transmitted light source. Trichomycete thalli were teased out of the gut with fine-tip forceps and insect pins mounted in pin vises (Grobet USA). Thalli were transferred to water on a microscope slide (wet mounted) and examined with a compound microscope (with either phase contrast or differential interference contrast illumination) for spores and other taxonomically significant characteristics (Lichtwardt et al 2001).

Digital photomicrographs were taken after semipermanent voucher slides were made by infiltrating specimens with a drop of lactophenol cotton blue ( $200 \mathrm{~g}$ phenol, $0.5 \mathrm{~g}$ cotton blue, $400 \mathrm{~mL}$ glycerol, $200 \mathrm{~mL}$ lactic acid and $200 \mathrm{~mL}$ distilled water) placed on the edge of the cover slip, then, after removing excess stain, sealing the edges of the cover slip with clear fingernail polish (Lichtwardt et al 2001). All measurements given in the species descriptions below were made from material stained with lactophenol cotton blue.

Where possible species were identified with the LUCID keys for trichomycetes available at the University of Kansas Website (Lichtwardt et al 2004). Voucher specimens of new species were deposited in the herbarium (SANU), College of Life Science, Shaanxi Normal University, Xi'an, 710062, Shaanxi, People's Republic of China.

\section{RESULTS}

We recorded four new species of trichomycetes, eight previously described species and four that were identified only to genus due either to insufficient material available or to inadequate morphological data to assign them to a species (TABLE II). Details on the new species are provided below as well as the 
TABLE I. Collection dates, coordinates and descriptions of sites for survey of trichomycetes in Qinling Mountains, western China

\begin{tabular}{|c|c|c|c|c|c|}
\hline Year & $\begin{array}{c}\text { Site } \\
\text { number }\end{array}$ & Site name & $\begin{array}{l}\text { Collection } \\
\text { date }\end{array}$ & Coordinates & Site description \\
\hline \multirow[t]{4}{*}{2007} & 1 & Qing5 & 18 Apr & $\begin{array}{c}33^{\circ} 48^{\prime} 42^{\prime \prime} \mathrm{N} \\
108^{\circ} 59^{\prime} 53^{\prime \prime} \mathrm{E}\end{array}$ & $\begin{array}{l}\text { South side Qinling Mountains, } 1000 \mathrm{~m} \text {, Hao } \\
\text { River, Nui Bei Liang Conservation Area, } \\
\text { shallow, rocky stream, boulders and } \\
\text { cobblestone, pH 7.6, } 15 \mathrm{C}\end{array}$ \\
\hline & 2 & Qing6 & 18 Apr & $\begin{array}{l}33^{\circ} 48^{\prime} 41^{\prime \prime} \mathrm{N} \\
108^{\circ} 59^{\prime} 53^{\prime \prime} \mathrm{E}\end{array}$ & Downstream of Qing5, shallow pool, $\mathrm{pH} 7.7,14 \mathrm{C}$ \\
\hline & 3 & Qing7 & 20 Apr & $\begin{array}{l}33^{\circ} 48^{\prime} 47^{\prime \prime} \mathrm{N} \\
108^{\circ} 59^{\prime} 49^{\prime \prime} \mathrm{E}\end{array}$ & $\begin{array}{l}\text { Upstream of Qing5, shallow, rocky stream, } \\
\text { boulders and cobblestone, } \mathrm{pH} 7.6,13 \mathrm{C}\end{array}$ \\
\hline & 4 & Qing8 & $24 \mathrm{Apr}$ & $\begin{array}{c}33^{\circ} 55^{\prime} 40^{\prime \prime} \mathrm{N} \\
108^{\circ} 50^{\prime} 37^{\prime \prime} \mathrm{E}\end{array}$ & $\begin{array}{l}\text { North side Qinling Mountains, } 1000 \mathrm{~m} \text {, Feng Yu } \\
\text { Forest Park, Feng Yu river, shallow, rocky stream, } \\
\text { boulders and cobblestone, pH 8.0, } 12 \mathrm{C}\end{array}$ \\
\hline \multirow[t]{7}{*}{2006} & 5 & Qingl1 & 18 Apr & $\begin{array}{c}33^{\circ} 33^{\prime} 14^{\prime \prime} \mathrm{N} \\
108^{\circ} 32^{\prime} 25^{\prime \prime} \mathrm{E}\end{array}$ & $\begin{array}{l}\text { South side Qinling Mountains, Yue River near } \\
\text { town of Xunyangba, shallow rocky stream, } \\
\text { boulders and cobblestone, pH 8.1, } 14 \mathrm{C}\end{array}$ \\
\hline & 6 & Qingl2 & $18 \mathrm{Apr}$ & $\begin{array}{l}33^{\circ} 26^{\prime} 01^{\prime \prime} \mathrm{N} \\
108^{\circ} 26^{\prime} 47^{\prime \prime} \mathrm{E}\end{array}$ & $\begin{array}{l}\text { South side Qinling Mountains, Chang'an River } \\
\text { in front of research station, Huoditang, shallow } \\
\text { stream, small rock and cobble, no } \mathrm{pH} \text { or } \\
\text { temperature recorded. }\end{array}$ \\
\hline & 7 & Qingl3 & 18 Apr & $\begin{array}{c}33^{\circ} 26^{\prime} 07^{\prime \prime} \mathrm{N} \\
108^{\circ} 26^{\prime} 49^{\prime \prime} \mathrm{E}\end{array}$ & $\begin{array}{l}\text { South side Qinling Mountains, } 1500 \mathrm{~m} \text {, small } \\
\text { stream beside research station, Huoditang, } \\
\text { flowing into Chang'an River, stream about } 2 \mathrm{~m} \\
\text { wide, shallow, cobble substrate, no pH or } \\
\text { temperature recorded. }\end{array}$ \\
\hline & 8 & QinlN1 & 21-Apr & $\begin{array}{c}33^{\circ} 56^{\prime} 42^{\prime \prime} \mathrm{N} \\
108^{\circ} 55^{\prime} 33^{\prime \prime} \mathrm{E}\end{array}$ & $\begin{array}{l}\text { North side Qinling Mountains, } 1000 \mathrm{~m} \text {, Hao } \\
\text { River, Nui Bei Liang conservation area, } \\
\text { shallow, rocky stream, boulders and } \\
\text { cobblestone, no pH or temperature recorded. }\end{array}$ \\
\hline & 9 & QinlN2 & $21 \mathrm{Apr}$ & No coordinates recorded & $1.5 \mathrm{~km}$ upstream from QinlN1 \\
\hline & 10 & QinlN3 & $21 \mathrm{Apr}$ & No coordinates recorded & $1.5 \mathrm{~km}$ downstream from QinlN1 \\
\hline & 8 & Qing4 & $31 \mathrm{Dec}$ & & Same site as QinlN1 \\
\hline \multirow[t]{2}{*}{2005} & 11 & Haopingsi & $25 \mathrm{Jul}$ & $\begin{array}{c}34^{\circ} 04^{\prime} 87^{\prime \prime} \mathrm{N} \\
107^{\circ} 41^{\prime} 64^{\prime \prime} \mathrm{E}\end{array}$ & $\begin{array}{l}\text { North side Qinling Mountains, } 1300 \mathrm{~m} \text {, shallow } \\
\text { rocky stream, boulders and cobblestone, near } \\
\text { research station, Haopingsi, no pH or } \\
\text { temperature recorded. }\end{array}$ \\
\hline & 8 & QinlN1 & 28 May & & Same site as QinlN1 \\
\hline
\end{tabular}

names of previously described species found in these collections from western China.

\section{TAXONOMY}

Legeriomyces grandis Juan Wang, Strongman \& S.Q. $\mathrm{Xu}$, sp. nov. FIGS. 1-3 Mycobank MB 513331

Thallus sparse ramosus, haptero compacto digitato exoriens. Trichosporae magnae, 52-55 $\times 11-12.5 \mu \mathrm{m}$, valde obpyriformes, distaliter usque $6.5-8 \mu \mathrm{m}$ latae attenuatae, duas appendices non helicoides intra cellulam genitalem ante liberationem sporarum ferentes, sine collo. Zygosporae non observatae. In proctodaeo nympharum Baetidarum.

Thallus sparsely branched, arising from a compact digitate holdfast (FIG. 2). Trichospores large, 52-55 $\times$
$11-12.5 \mu \mathrm{m}$, strongly obpyriform, tapering to $6.5-8 \mu \mathrm{m}$ wide distally (FIGS. 1,3) with two long, thin appendages (FIG. 3) that are not coiled within the sporogenous cell before trichospore release, no collar. Zygospores not seen. In the hindgut of mayfly nymphs (Baetidae).

Etymology. From the Latin grandis referring to the large trichospores of this species.

Specimens examined. CHINA. SHAANXI PROVINCE: Hao River near Nui Bei Liang Conservation Area on the north side of the Qinling Mountains (site 8, TABLE I). Lactophenolcotton blue-stained slide prepared from the hindgut of a mayfly nymph (Baetidae) collected 31 Dec 2006 (HOLOTYPE SANU).

Commentary. Trichospores in Legeriomyces grandis are longer and wider than those in any of the six described species in the genus and are strongly 
TABLE II. List of trichomycete species, their hosts and collection dates from 11 sites in western China

\begin{tabular}{|c|c|c|c|}
\hline Species & Site $^{a}$ & Host & Date collected \\
\hline \multirow[t]{5}{*}{ Caudomyces japonicus } & 4 & Antocha sp. (Tipulidae) & 24 Apr 2007 \\
\hline & 3 & Antocha sp. & 20 Apr 2007 \\
\hline & 2 & Antocha sp. & 18 Apr 2007 \\
\hline & 5 & Antocha sp. & 18 Apr 2006 \\
\hline & 11 & Antocha sp. & 11 July $2005 ; 12$ Sept 2005 \\
\hline \multirow[t]{4}{*}{ Gauthieromyces indicus } & 2 & mayflies (Ephemeroptera) & 18 Apr 2007 \\
\hline & 4 & mayflies & $24 \operatorname{Mar} 2007$ \\
\hline & 5 & mayflies & 18 Apr 2006 \\
\hline & 8 & mayflies & 28 May 2005 \\
\hline \multirow[t]{6}{*}{ Glotzia ephemeridarum $^{\mathrm{b}}$} & 4 & mayflies & 24 Apr 2007; 24 Mar 2007 \\
\hline & 3 & mayflies & 20 Apr 2007 \\
\hline & 2 & mayflies & 18 Apr 2007 \\
\hline & 5 & mayflies & 18 Apr 2006 \\
\hline & 8 & mayflies & 21Apr 2006 \\
\hline & 8 & mayflies & 31 Dec 2006 \\
\hline Legeriomyces sp. & 11 & mayflies & 11 July 2005 \\
\hline Legeriomyces grandis ${ }^{c}$ & 8 & mayflies & 31 Dec 2006 \\
\hline Legeriomyces ramosus ${ }^{\mathrm{b}}$ & 8 & mayflies & 31 Dec 2006 \\
\hline Legeriosimilis elegans & 7 & mayflies & 18 Apr 2006 \\
\hline Paramoebidium bacillare & 2 & stonefly (Leuctridae) & 18 Apr 2007 \\
\hline Paramoebidium spp. & all sites & $\begin{array}{l}\text { mayflies, stoneflies, midges } \\
\text { (Chironomidae) }\end{array}$ & all dates \\
\hline Smittium culicis ${ }^{\mathrm{b}}$ & 5 & midges & 18 Apr 2006 \\
\hline \multirow[t]{3}{*}{ Smittium shaanxiense } & 4 & midges & $24 \operatorname{Mar} 2007$ \\
\hline & 6 & midges & 18 Apr 2006 \\
\hline & 3 & midges & 20 Apr 2007 \\
\hline Smittium simulii & 4 & midges & 24 Apr 2007 \\
\hline Smittium sp. 1 & 6 & midges & 18 Apr 2006 \\
\hline Smittium sp. 2 & 11 & Antocha sp. & 11 July 2005 \\
\hline Stachylina gravicaudata & 4 & midges & 24 Apr 2007 \\
\hline \multirow[t]{2}{*}{ Stachylina penetralis } & 6 & midges & 18 Apr 2006 \\
\hline & 4 & midges & 24 Apr 2007 \\
\hline
\end{tabular}

${ }^{a}$ Site numbers are those in TABLE I.

${ }^{\mathrm{b}}$ First records of these species in China.

${ }^{\mathrm{c}}$ Species in boldface are newly described in this report.

obpyriform as is the type species, Legeriomyces ramosus Pouzar (Lichtwardt 2004). Baetimyces ancorae L.G. Valle \& Santam. is found in mayfly hosts and trichospores are in the same size range (Valle and Santamaria 2002). However B. ancorae trichospores are subcylindrical, with a small collar and have two appendages with characteristic conspicuous coiling within the sporogenous cell that differ from L. grandis. Two species, Genistelloides helicoides M.C. Williams \& Lichtw. and Genistelloides amplispora M.M. White \& Lichtw., as well as Lancisporomyces nemouridarum Strongman \& M.M. White, have trichospores in this size range but they are not obpyriform and inhabit the gut of stonefly hosts (Lichtwardt 2004).

Legeriosimilis elegans Strongman, Juan Wang \& S.Q. $\mathrm{Xu}$, sp. nov. FIGS. 4-7
Thallus sparsus, 2-3 ramis haptero cupulato quod materiam in pariete interiore proctodaei secernit exorientibus. Trichosporae (2-4) in apicibus ramorum brevium, leniter obpyriformes, $54-56 \times 7-8 \mu \mathrm{m}, 3$ appendices latas ferentes, sine collo. Zygosporae non observatae. Ad proctodaeum nympharum Baetidarum affixus.

Thallus sparse with 2-3 branches (FIG. 4) arising from a cup-shape holdfast that secretes material onto the hindgut lining (FIGS. 6, 7). Trichospores (2-4) on tips of short branches slightly obpyriform, 54-56 $\times 7-$ $8 \mu \mathrm{m}$, with three broad appendages, no collar (FIG. 5). Zygospores not seen. Attached to hindgut of mayfly nymphs (Baetidae).

Etymology. From the Latin elegans, in reference to the elegant shape of the trichospores.

Specimens examined: CHINA. SHAANXI PROVINCE: Huoditang (site 7, TABLE I). Lactophenol-cotton bluestained slide prepared from the hindgut of a mayfly nymph (Baetidae) collected 18 Apr 2006 from a small stream

Mycobank MB 513332 


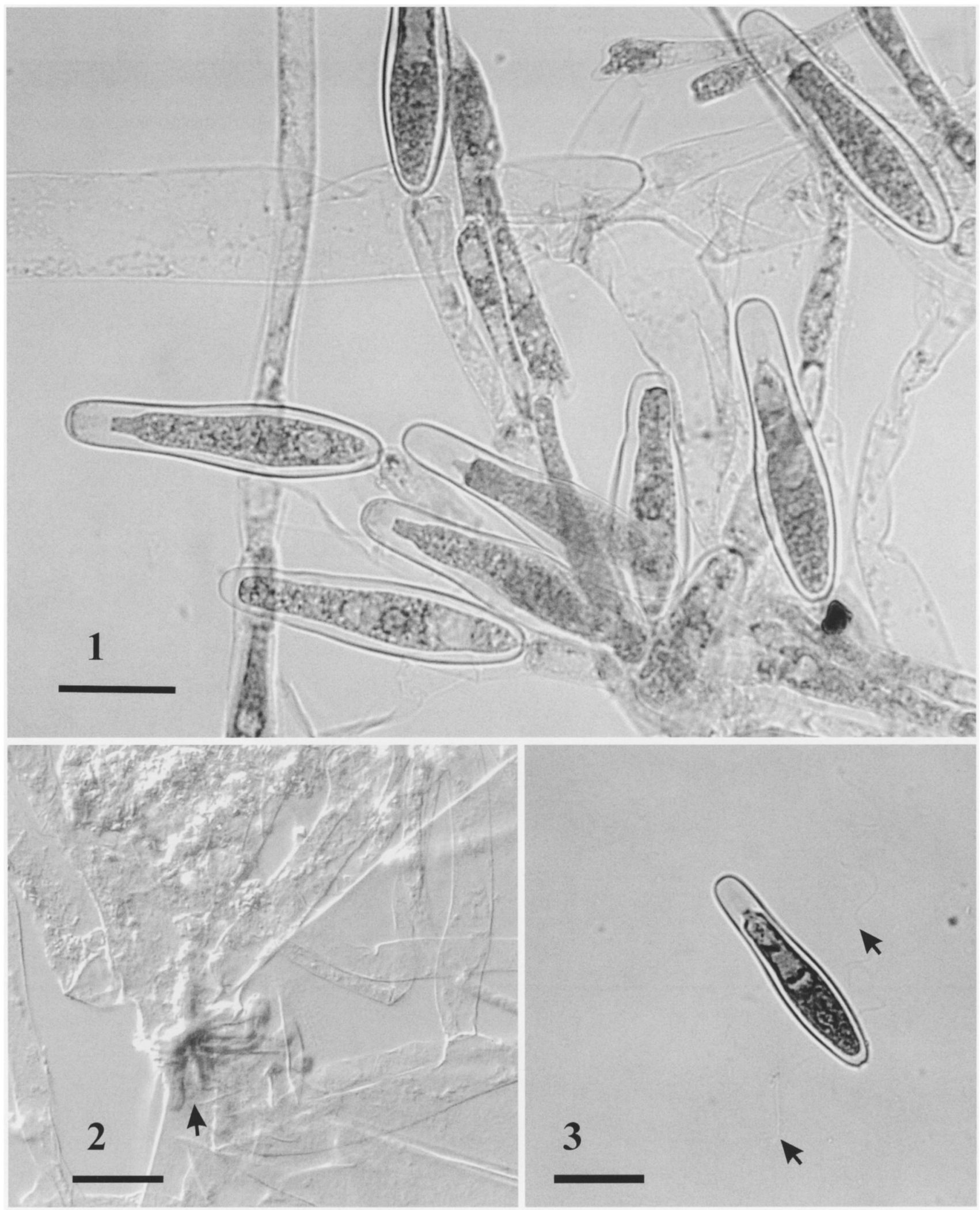

FIGS. 1-3. Legeriomyces grandis. 1. Trichospores attached to fertile branches of thallus. 2. Holdfast branched (arrow) imparting a digitate appearance. 3. Released trichospore with two long fine appendages (arrows). Bars $=20 \mu \mathrm{m}$. 

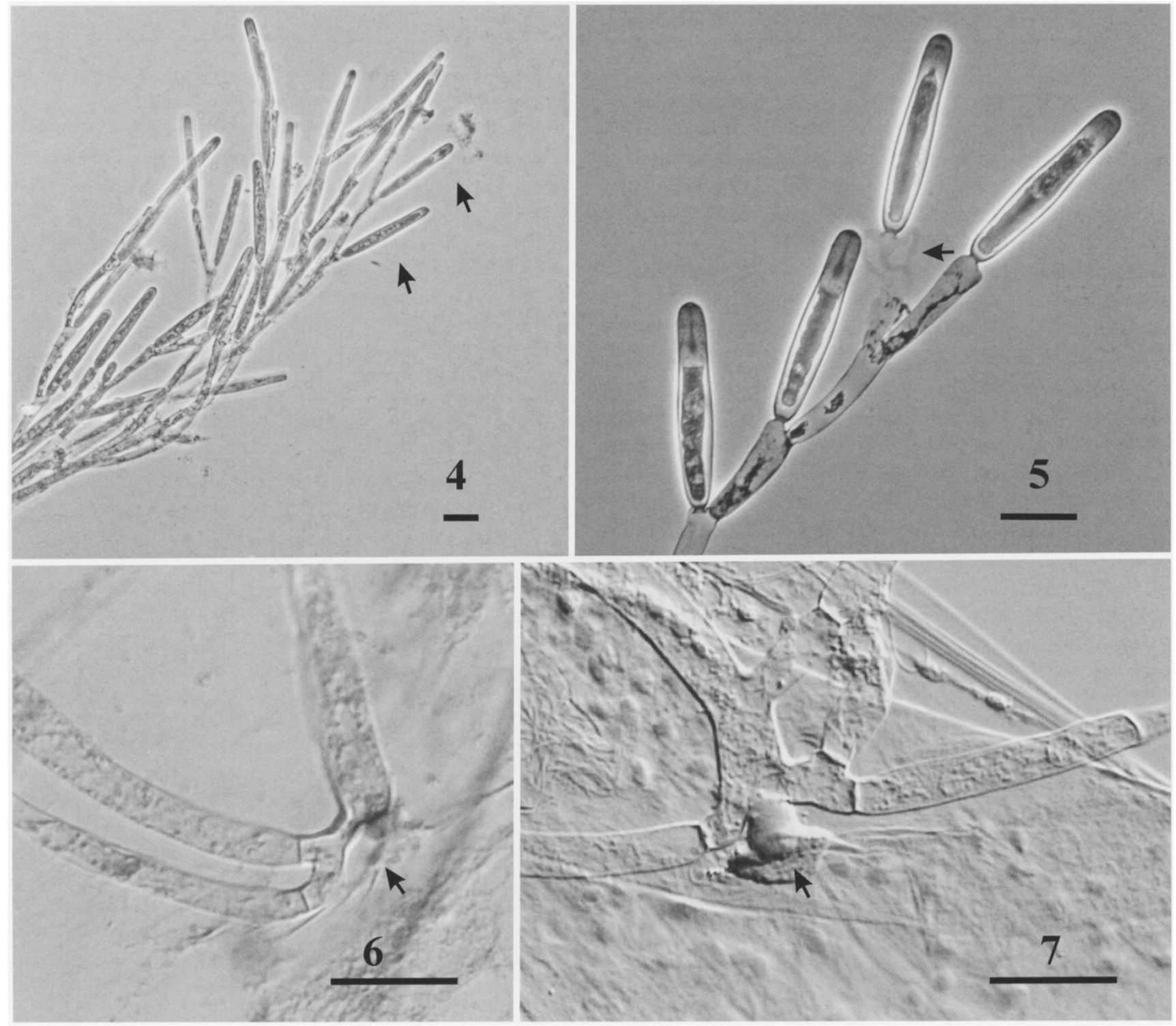

FIGS. 4-7. Legeriosimilis elegans. 4. Trichospores (arrows) attached to fertile branches on the thallus. 5. Three attached and one trichospore detaching from thallus, exposing three broad appendages (arrow). 6. Base of a thallus with cup-shape holdfast (arrow). 7. Holdfast with secreted material (arrow) attaching it to the hindgut lining. Bars $=20 \mu \mathrm{m}$.

running into Chang'an River, Ningshan County, on the south side of the Qinling Mountains (HOLOTYPE SANU).

Commentary. Trichospores of Legeriosimilis elegans are longer than those in the other four species described: Legeriosimilis tricaudata M.C. Williams \& Lichtw. [(33-)47(-52) $\times(7-) 9.5(-11) \mu \mathrm{m}] ;$ Legeriosimilis europaeus M.M. White \& Lichtw. (33-40 × 6$8 \mu \mathrm{m})$; Legerisimilis leptocerci Strongman \& M.M. White (24-28 $\times 5.5-6 \mu \mathrm{m})$ and Legeriosimilis whitneyi Strongman \& M.M. White $(20-26.5 \times 4.5-6 \mu \mathrm{m})$ (Lichtwardt 2004). Trichospores of $L$. elegans are also longer than an unnamed Legeriosimilis with trichospores 30-32 $\times$ $6-8 \mu \mathrm{m}$ collected from USA (White et al 2006). The length of $L$. elegans trichospores overlap those of Legeriomyces grandis described above, and both species come from baetid mayfly hosts but are easily distinguished from one another by the number and appearance three broad appendages in L. elegans and two fine appendages in $L$. grandis.

Paramoebidium bacillare Strongman, Juan Wang \& S.Q. Xu, sp. nov. Figs. 8-10 Mycobank MB 513333

Thallus intra proctodaeum haptero laterali bulboso et materia fibrosa secreta affixus. Thallus ad hapteron valde constrictus, ex haptero inaequaliter crescens pro brachio majore antico distaliter angustato et brachio minore postico quod post extenionem partialem brachii antici augescit. Alii status auctus non observati. Proctodaeum nympharum Leuctridarum incolens. 
Thallus attached to the hindgut lining by a lateral bulbous holdfast and fibrous secreted material (Figs. 8, 10). Thallus strongly constricted at the holdfast, developing unequally from the holdfast into a larger anterior arm tapered distally and a smaller posterior arm that develops after the anterior arm has partially extended (FIGS. 8, 9). No other developmental stages were seen. Attached to hindgut of Leuctridae nymphs.

Etymology. From the Latin bacillum meaning rod or staff, in reference to the shape of the thallus.

Specimens examined: CHINA. SHAANXI PROVINCE: Hao River near Nui Bei Liang Conservation Area on the south side of the Qinling Mountains (site 2, TABLE I). Lactophenol-cotton blue-stained slide prepared from the hindgut of a stonefly nymph (Leuctridae) collected $18 \mathrm{Apr}$ 2007 from a small pool in the Hao River (HOLOTYPE SANU).

Commentary. No other species of Paramoebidium have vegetative thallus characteristics like those seen in $P$. bacillare (Lichtwardt 2004). The large, bulbous holdfast and the constriction of the thallus forming two unequal sections in $P$. bacillare distinguishes this species from Paramoebidium stipula Strongman \& M.M. White from nemourid stonefly nymphs, which also have prominent lateral holdfast near the base of the thallus (Strongman and White 2006). Paramoebidium bibrachium M.C. Williams \& Lichtw. and Paramoebidium papillatum Lichtw. \& M.C. Williams are found in mayfly guts and both have lateral holdfasts (Lichtwardt 2004), but neither have the conspicuous, stalked, bulbous holdfast like $P$. bacillare.

Smittium shaanxiense Juan Wang, Strongman \& S.Q. $\mathrm{Xu}$, sp. nov. FIGS. 11-16 Mycobank: MB 513334

Thallus densus ramificatione abunda, intra proctodaeum haptero inconspicuo affixus. Trichosporae dimorphae: trichosporae magnae in medio leviter tumidae, 33.5-46 $\times$ 8.5-14 $\mu \mathrm{m}$, collo longo $(11-18 \mu \mathrm{m})$ et appendice unica longa gracilique instructae; trichosporae parvae, quae in isdem ramis ac sporae magnae adesse possunt, ovales, 9-12 $\times 4.5-7 \mu \mathrm{m}$, collo $(11-14 \mu \mathrm{m})$ et appendice unica instructae. Zygosporae (Typus II) biconicae, 56.5-67 $\times$ 7.5$11.5 \mu \mathrm{m}$, in zygosporophoro ex hyphis conjugatis directe orienti portatae. Zygosporae ubi liberatae collo (15.5-19.5 $\times 3-4 \mu \mathrm{m})$ et appendice unica tenui instructae. Ad proctodaeum larvarum Chironomidarum affixus.

Thallus dense with prolific branching, attached to the hindgut lining by an inconspicuous holdfast (FIG. 11). Trichospores dimorphic (FIGS. 12, 16) with large trichospores slightly swollen medially, 33.5-46 $\times$ 8.5-14 $\mu \mathrm{m}$, possessing a long (11$18 \mu \mathrm{m})$ collar and one long, thin appendage (FIG. 14). Small trichospores, which can occur on the same branches as larger trichospores (FIG. 12), oval, $9-12 \times 4.5-7 \mu \mathrm{m}$, with a collar $(11-14 \mu \mathrm{m})$ (FIG. 16) and single appendage. Zygospores (Type II) are biconical, 56.5-67 $\times$ 7.5-11.5 $\mu \mathrm{m}$ (FIGS. 13$15)$, borne on a zygosporophore arising directly from conjugated hyphae. Zygospores have a collar (15.5$19.5 \times 3-4 \mu \mathrm{m})$ and one long, thin appendage (FIG. 15). Attached to hindgut of midge larvae (Chironomidae).

Etymology. Derived from the location where the species was discovered, Shaanxi Province, in China.

Specimens examined. CHINA. SHAANXI PROVINCE: Feng Yu River near Nui Bei Liang Conservation Area on the north side of the Qinling Mountains (site 4, TABLE I). Lactophenol-cotton blue-stained slide prepared from the hindgut of a midge larva (Chironomidae) collected $24 \mathrm{Mar}$ 2007 (HOLOTYPE SANU). The holotype slide contains both large and small trichospores as well as zygospores. Lactophenol-cotton blue-stained slide contains mostly trichospores (both types) on thalli (ISOTYPE SANU). Also collected at site 6 (Qingl2), Huoditang, Chang'an River 8 Apr 2006 and at site 3 (TABLE I) in Hao River 20 Apr 2007, both on the south side of the Qinling Mountains.

Commentary. Smittium naiadis Strongman \& S.Q. $\mathrm{Xu}$ and Smittium nodifixum Strongman \& S.Q. Xu were described from chironomids, as well as Smittium chinliense Strongman \& S.Q. Xu from tipulid hosts, collected from the same area in western China as Smittium shaanxiense (Strongman and $\mathrm{Xu}$ 2006). The other species from China differ in trichospore dimensions and thallus characteristics, so they are easily distinguished from $S$. shaanxiense. Several Smittium spp. are dimorphic, producing two morphologically different trichospores (Lichtwardt 2004). Of these Smittium biforme M.M. White \& Lichtw., Smittium dimorphum Lichtw. \& M.C. Williams, Smittium ditrichosporum Strongman, Smittium esteparum Ferrington, Lichtw. \& López-Lastra and Smittium orthocladii Manier (Lichtw.) share some characteristics with $S$. shaanxiense (Lichtwardt 2004). The large trichospore dimensions for $S$. biforme $(34-42 \times 9-12 \mu \mathrm{m}), S$. ditrichosporum $(32-48.5 \times(5-) 6.5-11 \mu \mathrm{m})$ and $S$. esteparum $(31-38 \times 4.5-6.5 \mu \mathrm{m})$ overlap S. shaanxiense, however the dimensions of the smaller trichospores and the zygospores differ and the trichospore collars are much shorter in S. biforme and S. esteparum (Lichtwardt 2004). Both large and small trichospores in Smittium dimorphum $(38-50 \times 5.5-6.5 \mu \mathrm{m}, 10-12 \times$ $5.5-6.5 \mu \mathrm{m})$ and $S$. orthocladii $[(25-) 30(-40) \times(6-)$ $7(-8) \mu \mathrm{m}, 8-10 \times 5-6 \mu \mathrm{m})]$ overlap somewhat $S$. shaanxiense, but both large and small trichospores are narrower and the zygospores are longer in both species (Lichtwardt 2004) compared to S. shaanxiense. Several other species in this large and variable genus have dimensions overlapping either the large or small trichospore or zygospore, so accurate identification will necessitate careful examination of thallus features, 


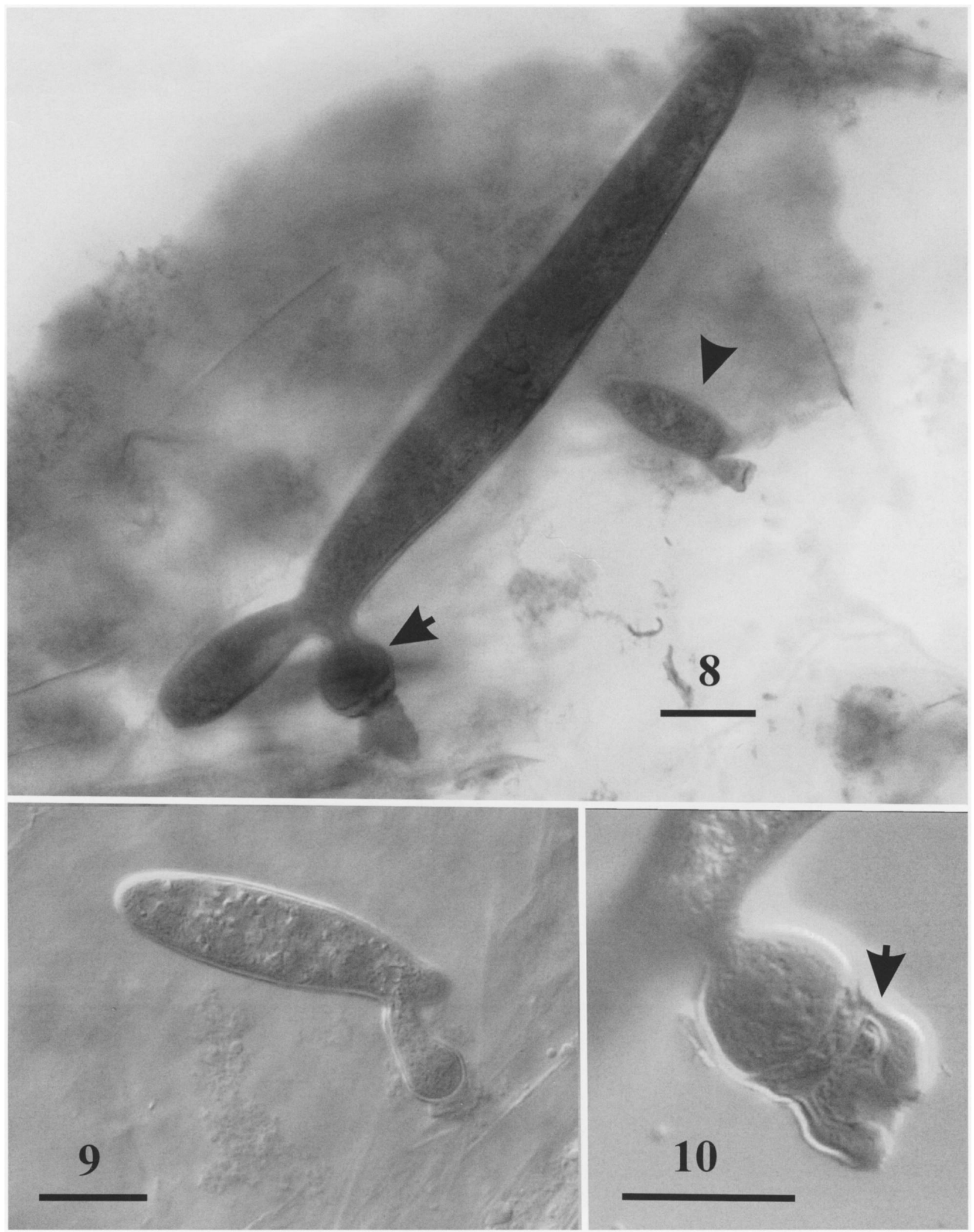

FIGS. 8-10. Paramoebidium bacillare. 8. Immature thallus with bulbous holdfast (arrow) and secreted material. Note the unequal division of the main axis of the thallus not apparent in the young thallus (arrowhead). 9. Young thallus. 10. Details of bulbous holdfast and secreted material (arrow). Bars $=20 \mu \mathrm{m}$. 


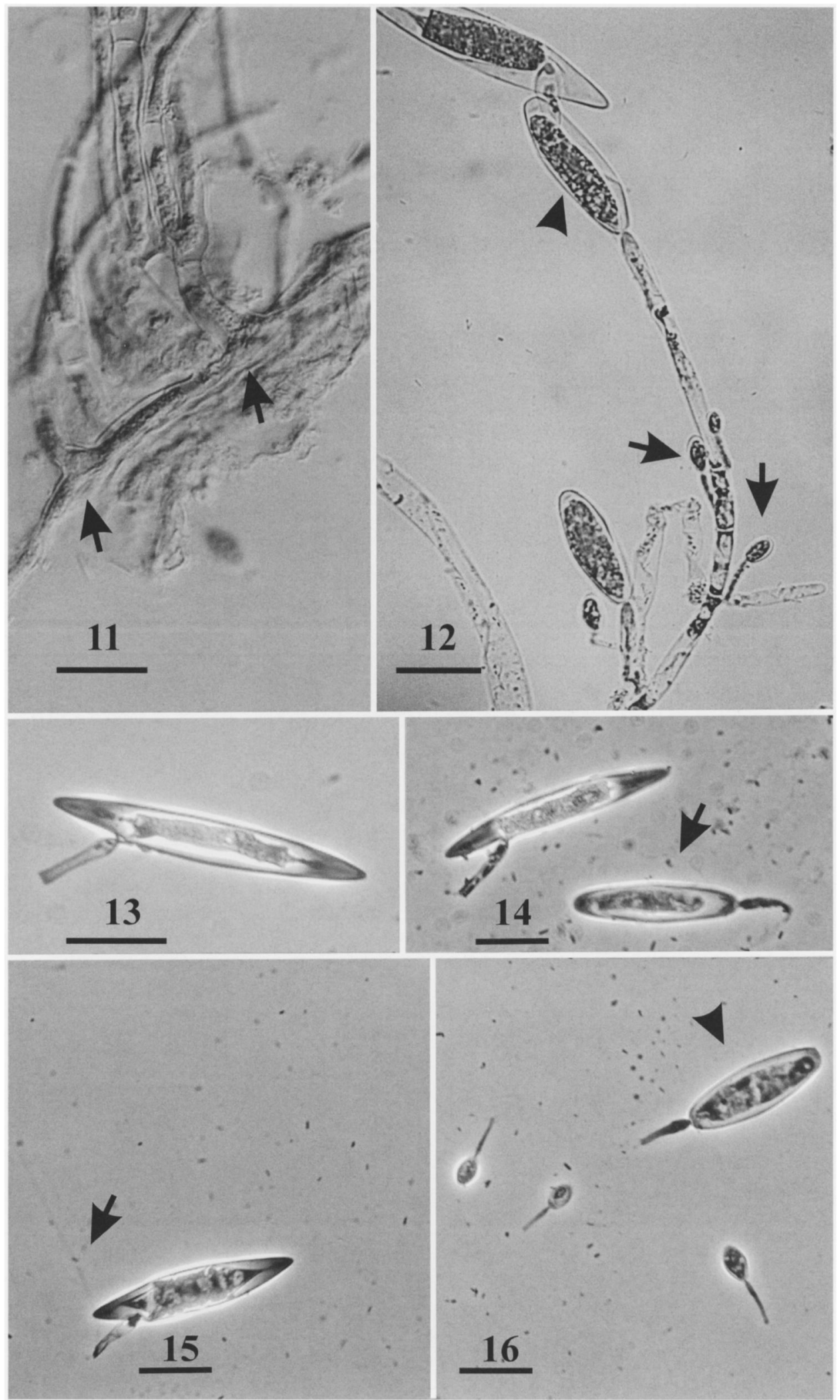

FIGS. 11-16. Smittium shaanxiense. 11. Basal section of thallus with inconspicuous holdfasts (arrows). 12. Fertile branch of a thallus with both large (arrowhead) and small trichospores (arrows). Part of an attached, terminal zygospore at the top of the figure. 13. Released zygospore. 14. The larger of the dimorphic trichospores (arrow) and a zygospore, both released from a thallus. Note the long collar on each spore type. 15. Released zygospore with a single, fine appendage. 16. Large (arrowhead) and small trichospores, both with long collars. Note the considerable size dimorphism. Bars $=20 \mu \mathrm{m}$. 


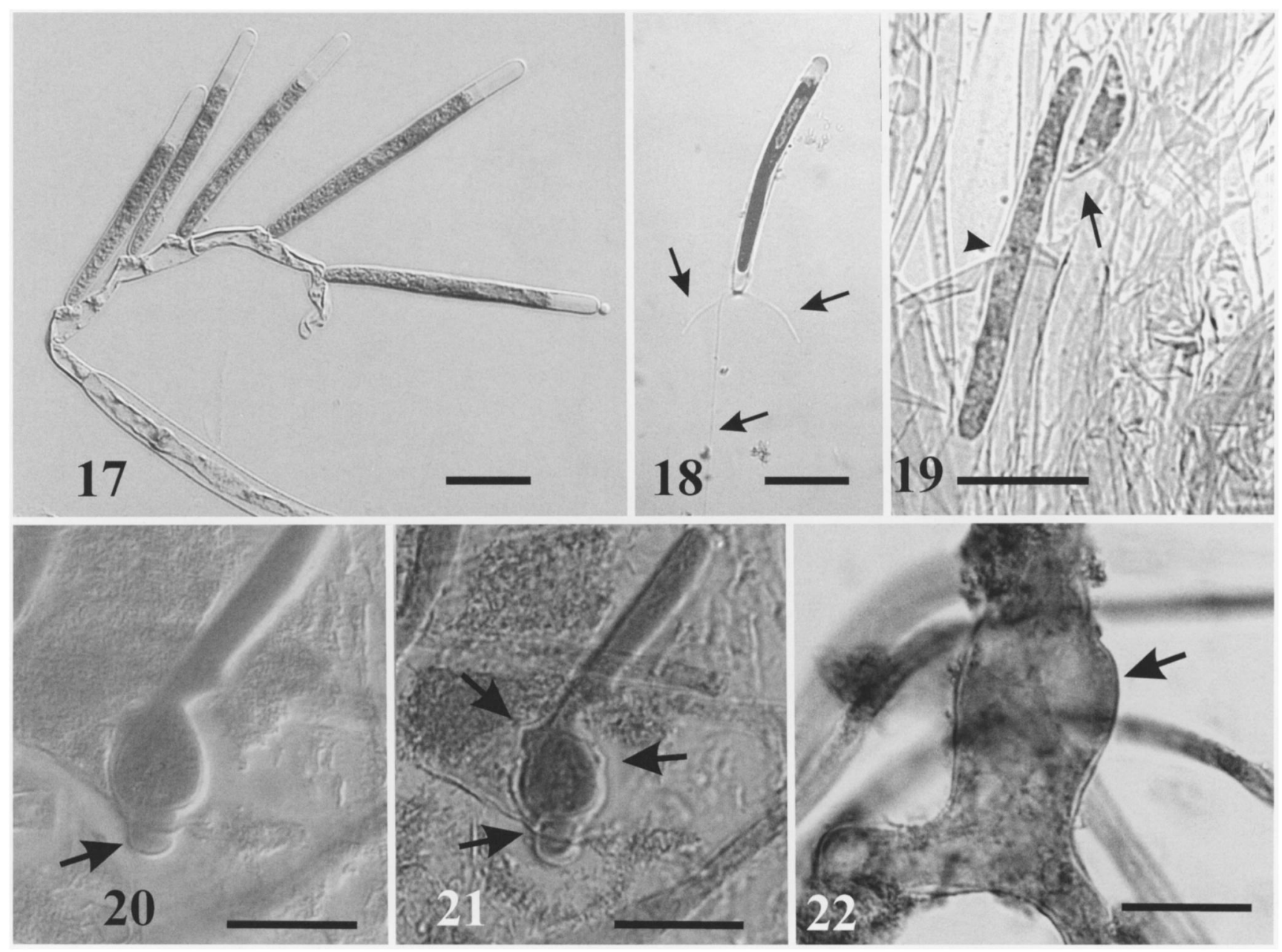

Figs. 17-22. Glotzia ephemeridarum. 17. Fertile thallus branchlet with five attached trichospores. 18. Released trichospore with three appendages (arrows). 19. A trichospore (arrowhead) and zygospore (arrow). 20-22. Holdfast development. 20. Bulbous basal cell with a large basal protrusion (arrow). 21. Older thallus and basal cell with three protrusions (arrows), presumably branches forming. 22. Swollen basal cell (arrow) of mature thallus with well developed branches. Bars $=20 \mu \mathrm{m}$.

in addition to size ranges for both trichospores and zygospores.

Other species. Four species of harpellid fungi, Caudomyces japonicus Lichtw., Kobayasi \& Indoh, Gauthieromyces indicus Misra \& Tiwara, Smittium simulii Lichtw., Stachylina penetralis Lichtw., and protistans (Paramoebidium spp.) all were reported from western China by Strongman and Xu (2006). Glotzia ephemeridarum Lichtw., Smittium culicis Manier and Stachylina gravicaudata Siri, M.M. White \& Lichtw. are reported for the first time in Asia extending the range of these species (TABLE II). In Asia Legeriomyces ramosus is known from India (Misra and Tiwari 2008) but this is a first report of it from China. The specimens of Glotzia ephemeridarum (FIGS. 17-22) had trichospore dimensions and appendages as well as zygospore features that were characteristic of the species (Lichtwardt 1972), but some young thalli had a strongly bulbous basal cell and holdfast (FIGS. 20-
22). Two species of Smittium and several Paramoebidium spp. were unidentifiable due to insufficient characteristics being available on the voucher slides (TABLE II).

\section{DISCUSSION}

Stachylina penetralis, Smittium simulii and Paramoebidium spp. were collected in western China (Strongman and $\mathrm{Xu}$ 2006) and these species along with Glotzia ephemeridarum, Legeriomyces ramosus and Smittium culicis, which are reported here for the first time, are all globally distributed (Lichtwardt et al 2001). Caudomyces japonicus is known only from Asia (Lichtwardt et al 1987) with a second species, $C$. longicollis, found in eastern Canada (Strongman 2007). Gauthieromyces indicus also is known only from Asia (Misra and Tiwari 2008) and there are two other species, the type, G. microspora Lichtw. from France 
(Lichtwardt 1983), and G. viviparous L.G. Valle, M.M. White \& Cafaro recently described from Mexico (Valle et al 2008). Therefore the members of these genera appear to be distributed widely. Similarly Stachylina gravicaudata was described only recently from USA (White et al 2006) but might be distributed more widely, given our collection of this species in China.

Most morphological features in the collection of Glotzia ephemeridarum from China fit the species description (FIGs. 17-19), however the bulbous basal cell (Figs. 20, 21) on the thallus is unusual for $G$. ephemeridarum (Lichtwardt 1972). The basal cell of the holdfast in G. ephemeridarum is branched and at maturity has a series of peg-like secreted holdfasts (Lichtwardt 1972), but there is considerable variation in the holdfast and associated basal cell among the Glotzia spp. (Lichtwardt 2004). For instance Glotzia incilis Strongman has a prominent bulbous basal cell and Glotzia centroptili Gauthier ex Manier \& Lichtwardt has a swollen basal cell with a lateral holdfast (Lichtwardt 2004). Young thalli of G. ephemeridarum in the Chinese collections had a conspicuous bulbous holdfast, often with one or two protrusions (FIGS. 2022). Older thalli had a swollen, branched basal cell so there is a considerable developmental change in the holdfast structure as the thallus matures (FIGs. 2022). Strongman and White (2008) described variation in the trichospore-bearing structures in Orphella avalonensis M.M. White, Lichtw. \& Colbo and suggested that there might be variation in characters that are taxonomically important due to developmental processes. Many trichomycetous fungi cannot be cultured, and collections done in typical surveys often do not provide sufficient material to trace the entire developmental process for a species. Whenever possible it would be useful to document developmental variation in taxonomically significant features such as trichospore, zygospore or overall thallus characteristics. The basal cell holdfast structure in the Chinese collections differs from the North American collections and this thallus structure changes as it develops, but sufficient similarity in trichospore structure and dimensions exist to identify the Chinese fungus as $G$. ephemeridarum.

The relatively short-term, small-scale surveys that have been conducted in China have produced a list of about 20 species of trichomycetes, including those in this report, with one new genus and eight new species described so far (Strongman and Xu 2006, Wang et al 2010). Nelder et al (2006) showed a dramatic increase in the number of harpellid trichomycete species described globally from only one host (black flies) and attributed this to an increase in surveys in areas that previously were not sampled. Therefore China with its vast area and large and varied hydrological features no doubt will continue to yield many new and interesting species of trichomycetes as surveys are conducted on a larger scale, including as many habitats and suitable hosts as possible.

\section{ACKNOWLEDGMENTS}

We thank Carolyn Bird, Chester Basin, Nova Scotia, for providing the Latin diagnoses and for making suggestions that helped improve the English versions of the descriptions. Dr RW Lichtwardt read a draft of the paper and offered helpful suggestions. Financial support for the field work was provided by the College of Life Science, Shaanxi Normal University (SNNU), and both SNNU and Saint Mary's University provided money for travel to DBS. Mr Yi Bai assisted us in the field and with some of the dissections.

\section{LITERATURE CITED}

Adler PH, Wang Z, Beard CE. 1996. First records of natural enemies from Chinese blackflies (Diptera: Simuliidae). Med Entomol Zool 47:291-292.

Chien C-Y, Hsieh Li-H. 2001. Occurrence of Trichomycetes in Taiwan. In: Misra JK, Horn BW, eds. Trichomycetes and other fungal groups. Enfield, New Hampshire: Science Publishers Inc. p 55-72.

Lichtwardt RW. 1972. Undescribed genera and species of Harpellales (Trichomycetes) from the guts of aquatic insects. Mycologia 64:167-197.

1983. Gauthieromyces, a new genus of Harpellales based on Genistella microspora. Mycotaxon 17:213-215.

. 1986. The Trichomycetes: fungal associates of arthropods. New York: Springer-Verlag. 343 p.

. 2004. Lucid keys to the Trichomycetes. http://www. nhm.ku.edu/ fungi/Lucid\%20Keys.html (accessed 1 May 2009).

—, Cafaro M, White MM. 2001. The Trichomycetes: fungal associates of arthropods. http://www.nhm.ku. edu/\%7Efungi/Monograph/Text/Mono.htm. (accessed 1 May 2009).

—_ Kobayasi Y, Indoh H. 1987. Trichomycetes of Japan. Trans Mycol Soc Japan 28:359-412.

MisraJK. 2002. Harpellales (Trichomycetes) do occur in India: first report of two species of Stachylina. Kavaka 30:71-75.

— - Tiwari VK. 2008. A new species of Gauthieromyces and range extensions for other Harpellales in India. Mycologia 100:94-98.

Nelder MP, Beard CE, Adler PH, Kim S-K, McCreadie JW. 2006. Harpellales (Zygomycota: Trichomycetes) associated with black flies (Diptera: Simuliidae): world review and synthesis of their ecology and taxonomy. Fungal Divers 22:121-169.

Strongman DB. 2007. Trichomycetes in aquatic insects from Prince Edward Island, Canada. Can J Bot 83:949963.

- White MM. 2006. New species of Lancisporomyces, Orphella and Paramoebidium, endosymbionts of stonefly nymphs from stream in Nova Scotia, Canada. Can J Bot 84:1478-1495. 
2008. Trichomycetes from lentic and lotic aquatic habitats in Ontario, Canada. Botany 86:14491466.

, Xu S. 2006. Trichomycetes from China and the description of three new Smittium species. Mycologia 98:479-487.

Valle LG, Santamaria S. 2002. Baetimyces, a new genus of Harpellales, and first report of Legeriomyces ramosus from the northeastern Iberian Peninsula. Mycologia 94: 321-326.
, White MM, Cafaro MJ. 2008. Harpellales in the digestive tracts of Ephemeroptera and Plecoptera nymphs from Veracruz, Mexico. Mycologia 100:149-163.

Wang J, Xu S, Strongman DB. 2010. Two new Harpellales inhabiting the digestive tracts of midge larvae and other trichomycetes from Tianshan Mountains, China. Mycologia 102:135-141.

White MM, Siri A, Lichtwardt RW. 2006. Trichomycete insect symbionts in Great Smoky Mountains National Park and vicinity. Mycologia 98:333-352. 